Section Editor Mitchell S.V. Elkind, MD, MS

Hector Gonzalez-Usigli, MD

Alberto J. Espay, MD, MSc, FAAN

Correspondence to

Dr. Espay:

alberto.espay@uc.edu

Download teaching slides: Neurology.org

Supplemental data at Neurology.org

\title{
Teaching Video NeuroImages: Semiology and localization of ballistic movements
}

回

Ballistic chorea (hemichorea-hemiballism) localizes to the subthalamic nucleus and its connections (video 1, figure, $\mathrm{Aa}$ ) or the putamen (video 2, figure, $\mathrm{Ab}$ ). Other large-amplitude hyperkinetic lesional movements can have similarly high localizing value. "Ballistic" tremor may develop months after recovering from ventrolateral thalamic strokes, in the thalamogeniculate vascular territory (video 3, figure, Ac and Ad). ${ }^{1}$ Similarly, "ballistic dystonia," limb dystonia with superimposed arrhythmic and jerky movements often referred to as myoclonic dystonia, may develop months after recovering from combined vascular lesions in the striatum and posterior thalamus (video 4, figure, Ae and Af). ${ }^{2}$ These motor complications, delayed by hours to days (hemiballism) or weeks to months (ballistic dystonia and tremor), have relatively distinct localization value to a narrow "ballistic corridor" in the basal ganglia and thalamus (figure, B).

\section{AUTHOR CONTRIBUTIONS}

Hector Gonzalez-Usigli: drafting/revising the manuscript, study concept or design, accepts responsibility for conduct of research and final approval, acquisition of data. Alberto J. Espay: drafting/revising the manuscript, study concept or design, analysis or interpretation of data, accepts responsibility for conduct of research and final approval, acquisition of data, study supervision.

\section{STUDY FUNDING}

No targeted funding reported.

\section{DISCLOSURE}

H. González-Usigli has received honoraria from Novartis, UCB, Teva, and Boehringer-Ingelheim. A. Espay is supported by the K23 career development award (NIMH, 1K23MH092735); has received grant support from CleveMed/Great Lakes Neurotechnologies, Davis Phinney Foundation, and Michael J. Fox Foundation; has received personal compensation as a consultant/scientific advisory board member for Solvay (now Abbvie), Chelsea Therapeutics, Teva, Impax, Merz, Solstice Neurosciences, Eli Lilly, and USWorldMeds; and has received honoraria from Novartis, UCB, Teva, the American Academy of Neurology, and the Movement Disorders Society. He serves as Associate Editor of Movement Disorders and Frontiers in Movement Disorders and on the editorial boards of Parkinsonism and Related Disorders and The European Neurological Journal. Go to Neurology.org for full disclosures.

\section{REFERENCES}

1. Lehericy S, Grand S, Pollak P, et al. Clinical characteristics and topography of lesions in movement disorders due to thalamic lesions. Neurology 2001;57:1055-1066.

2. Krystkowiak P, Martinat P, Defebvre L, Pruvo JP, Leys D, Destee A. Dystonia after striatopallidal and thalamic stroke: clinicoradiological correlations and pathophysiological mechanisms. J Neurol Neurosurg Psychiatry 1998;65:703-708. 


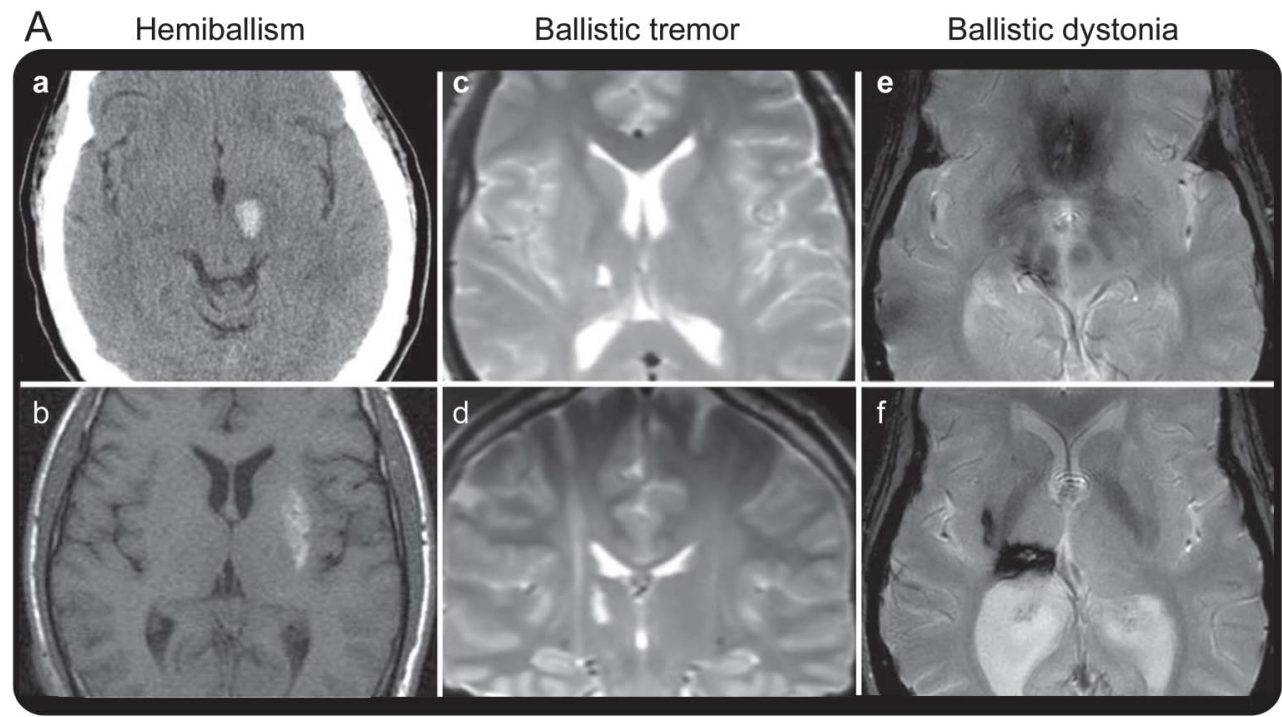

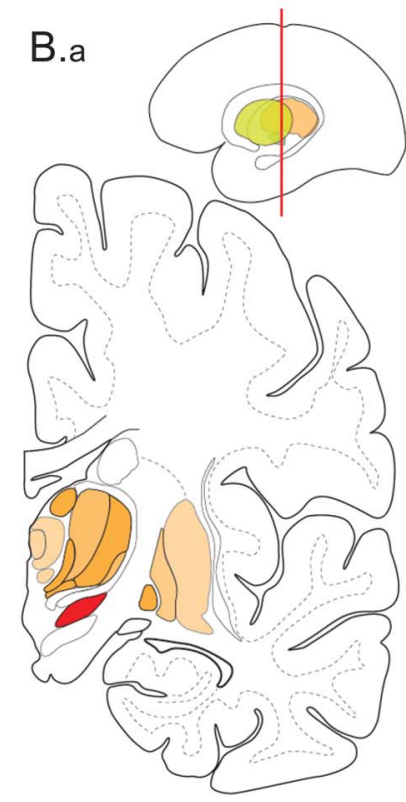

Subthalamic nucleus

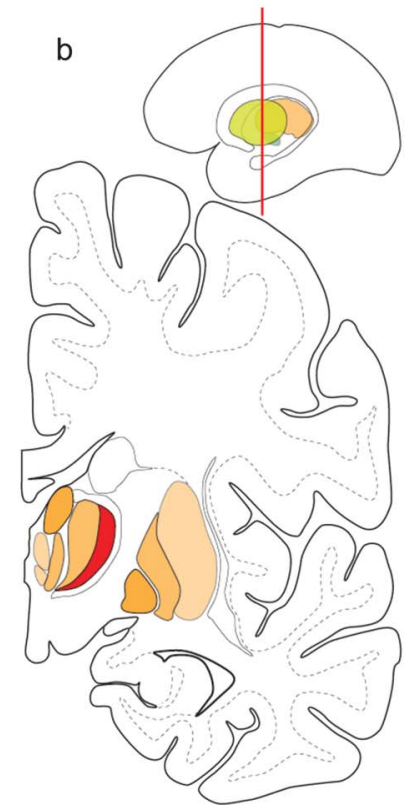

Ventrolateral thalamus

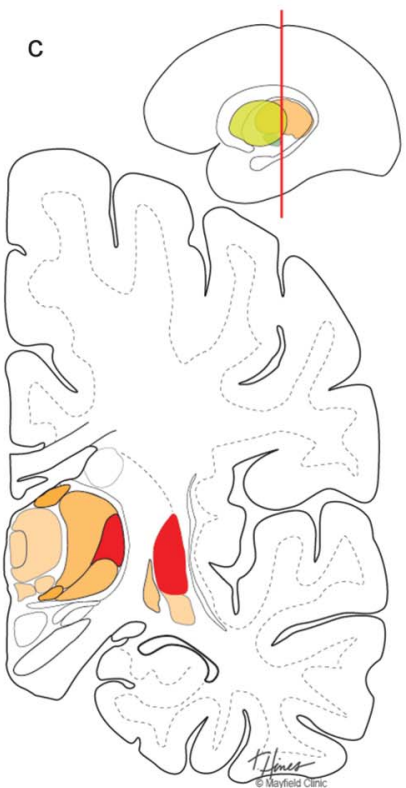

Dorsolateral putamen Posterior thalamus

(Aa) Head CT in a patient with hemichorea-hemiballism due to subthalamic stroke. An area of hyperintensity restricted to the region in and around the subthalamic nucleus represents a hypertensive hemorrhagic stroke (video 1). (Ab) Axial T1weighted brain MRI in a patient with hemichorea-hemiballism due to diabetic ketoacidosis. The area of T1 hyperintensity in the left posterior putamen was identified during an episode of severe diabetic ketoacidosis 3 weeks before the onset of right hemiballistic chorea (video 2). (Ac, Ad) Axial and coronal T2-weighted brain MRI in a patient with ballistic tremor. The area of T2 hyperintensity is restricted to the ventrolateral thalamus, corresponding to a stroke in the thalamogeniculate arterial territory (inferolateral arteries, $\mathrm{P} 2$ ) (video 3). (Ae, Af) Axial gradient echo brain MRI in a patient with ballistic dystonia. The regions of susceptibility artifact are due to hemosiderin deposition resulting from a remote hemorrhagic infarct involving the right posterior putamen, posterior thalamus, and upper midbrain, adjacent to the subthalamic nucleus (video 4). (Bac) Basal ganglia lesional "corridor" of ballistic movements. The ballistic movements have localizing value (shown in red) by narrowing the lesion in or around the subthalamic nucleus (a, hemiballism), ventrolateral thalamus (b, ballistic tremor), and dorsolateral putamen and posterior thalamus (c, myoclonic dystonia or "ballistic dystonia") (printed with permission: Mayfield Clinic). 


\section{Neurology}

\section{Teaching Video NeuroImages: Semiology and localization of ballistic movements Hector Gonzalez-Usigli and Alberto J. Espay \\ Neurology 2014;83;e56-e57 \\ DOI 10.1212/WNL.0000000000000622}

\section{This information is current as of July 21, 2014}

Updated Information \& Services

Supplementary Material

References

Subspecialty Collections

Permissions \& Licensing

Reprints including high resolution figures, can be found at: http://n.neurology.org/content/83/4/e56.full

Supplementary material can be found at: http://n.neurology.org/content/supp1/2014/07/20/83.4.e56.DC1 http://n.neurology.org/content/suppl/2014/07/20/83.4.e56.DC2

This article cites 2 articles, 2 of which you can access for free at: http://n.neurology.org/content/83/4/e56.full\#ref-list-1

This article, along with others on similar topics, appears in the following collection(s):

All Cerebrovascular disease/Stroke

http://n.neurology.org/cgi/collection/all_cerebrovascular_disease_strok

Clinical neurology examination

http://n.neurology.org/cgi/collection/clinical_neurology_examination

Information about reproducing this article in parts (figures,tables) or in its entirety can be found online at:

http://www.neurology.org/about/about_the_journal\#permissions

Information about ordering reprints can be found online:

http://n.neurology.org/subscribers/advertise

Neurology ${ }^{\circledR}$ is the official journal of the American Academy of Neurology. Published continuously since 1951, it is now a weekly with 48 issues per year. Copyright @ 2014 American Academy of Neurology. All rights reserved. Print ISSN: 0028-3878. Online ISSN: 1526-632X.

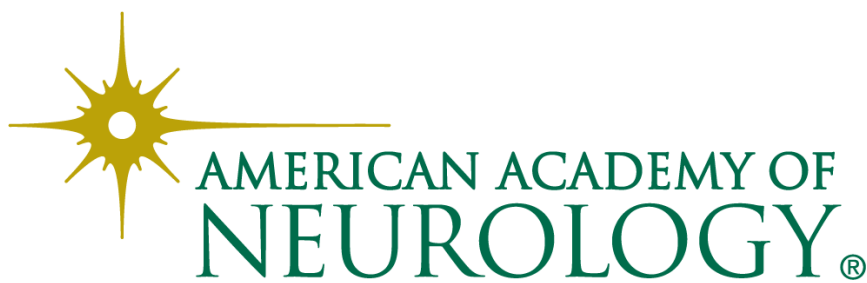

